\title{
Observation of Nitrate Radical in the Nocturnal Boundary Layer During a Summer Field Campaign in Pearl River Delta, China
}

\author{
Suwen $\mathrm{Li}^{1,2, *}$, Wenqing $\mathrm{Liu}^{2}$, Pinhua $\mathrm{Xie}^{2}$, Min Qin ${ }^{2}$, and Yijun Yang ${ }^{1}$ \\ ${ }^{1}$ Huaibei Normal University, Huaibei, China \\ ${ }^{2}$ Key Laboratory of Environmental Optical \& Technology, Anhui Institute of Optics \\ \& Fine Mechanics, Chinese Academy of Sciences, Hefei, China
}

Received 7 December 2010, accepted 26 July 2011

\begin{abstract}
From July 4 to 11, 2006 at Back Garden site $\left(23^{\circ} 28^{\prime} 86^{\prime \prime} \mathrm{N} ; 113^{\circ} 02^{\prime} 91^{\prime \prime} \mathrm{E}\right)$, nighttime nitrate radical $\left(\mathrm{NO}_{3}\right)$ was measured with a long path differential optical absorption spectroscopy (DOAS) during an intensive field campaign in the Pearl River Delta of China. The $\mathrm{NO}_{3}$ concentration in polluted air masses varied from 3.6 to $82.5 \mathrm{ppt}$ with an average level of $21.8 \pm$ 1.8 ppt. $\mathrm{NO}_{3}$ at these levels can play a significant role in oxidation of volatile organic compounds (VOCs). The calculated production rate of nitrate radical ranged from $8 \times 10^{5}$ to $2.98 \times 10^{7} \mathrm{~cm}^{-3} \mathrm{~s}^{-1}$, while its lifetimes spanned from between just several seconds to 650 seconds, with an average of 89 seconds. $\mathrm{N}_{2} \mathrm{O}_{5}$ levels were calculated with the average of $620 \pm 93 \mathrm{ppt}$ during this campaign. The possible scavenging processes for the nitrate radical were obtained by using a statistical analysis of the correlation between $\mathrm{NO}_{3}$ and $\mathrm{NO}$ levels, $\mathrm{NO}_{3}$ concentration and its production rate, and the $\mathrm{NO}_{3}$ lifetime and $\mathrm{NO}_{2}$ levels, respectively. Results showed that the direct losses were of importance at Back Garden in summer Pearl River Delta, China.
\end{abstract}

Key words: Nitrate radical, Differential optical absorption spectroscopy, Production rate, Lifetime, Loss process

Citation: Li, S., W. Liu, P.Xie, M. Qin, and Y. Yang, 2012: Observation of nitrate radical in the nocturnal boundary layer during a summer field campaign in Pearl River Delta, China.Terr. Atmos. Ocean. Sci., 23, 39-48, doi: 10.3319/TAO.2011.07.26.01(A)

\section{INTRODUCTION}

Nocturnal chemistry and physics play a crucial role in the conversion and removal of air pollutants such as nitrogen oxides and volatile organic compounds (VOCs), which determines the initial conditions for photochemistry during the following day (Platt et al. 1980; Wayne et al. 1991; Heintz et al. 1996; Geyer et al. 2001; Vrekoussis et al. 2004; Wood et al. 2005; Brown et al. 2006a). This is particularly true for the nitrate radical $\left(\mathrm{NO}_{3}\right)$. Following its first detection in the troposphere (Noxon et al. 1980; Platt et al. 1980), $\mathrm{NO}_{3}$ has been measured in polluted and clean background air under both continental and marine conditions (Platt et al. 1980; Wayne et al. 1991; Heintz et al. 1996; Geyer et al. 2001; Vrekoussis et al. 2004; Wood et al. 2005; Brown et al. 2006b). The nitrate radical has been identified as a key oxidant in the nighttime, which is responsible for the removal

\footnotetext{
* Corresponding author

E-mail: suwen_li2007@163.com
}

of many VOCs, especially monoterpenes. In addition, it has been surmised that the nitrate radical plays an important role in the non-photochemical conversion of nitrogen oxides to $\mathrm{HNO}_{3}$ (Platt et al. 1990; Bey et al. 2001; Geyer et al. 2001; Wood et al. 2005; Brown et al. 2006a).

The Pearl River Delta (PRD) is one of the areas which have experienced the fastest economic development in China. Urbanization in the PRD is characterized by city clusters with three mega-cities (Guangzhou, Hong Kong and Macao) and many medium-small cities (such as Zhuhai, Dongguan and Zhaoqing) linked by dense highway networks. Fueled by higher demands for energy, mobility and communications, the economy has increased at an impressive speed for decades. In consequence, coal smog and traffic exhaust together cause serious photochemical smog and particulate pollution problems on a large scale both in urban and regional areas (http://www.info.gov.hk/info/gprd/).

In this paper, we present the measurements of $\mathrm{NO}_{3}$ by long path differential optical absorption spectroscopy 
(DOAS) and an examination of other gases $\left(\mathrm{NO}_{2}, \mathrm{O}_{3}\right.$ and NO), which were carried out from July 4 to 11, 2006 at Back Garden (23⒉ $28^{\prime} 86^{\prime \prime} \mathrm{N}$; $\left.113^{\circ} 02^{\prime} 91^{\prime \prime} \mathrm{E}\right)$ in Guangzhou during an intensive field campaign in PRD, China. Our main purpose was to determine the concentrations, production rates, lifetimes, and possible loss processes of the nitrate radical during this field campaign in the PRD, China.

\section{THE EXPERIMENT}

\subsection{Location}

The concentrations of nitrate radical were monitored using a long path DOAS instrument ( $\mathrm{Li}$ et al. 2007) from July 4 to 11, 2006 at Back Garden located in the northwest quadrant of the Pearl River Delta, which was included as a part of the PRD-2006 summer field campaign. The DOAS setup was deployed on the third floor of a 4-floor building and an array of retro-reflectors was placed in another building, $10 \mathrm{~m}$ above the ground, resulting in a total atmospheric optical path of $3.1 \mathrm{~km}$ on average. A lake with dense foliage was beneath the optical path located around the measurement site. Figure 1 shows the map of monitoring site during PRD summer field campaign. Analysis of the $\mathrm{NO}, \mathrm{NO}_{2}$, and $\mathrm{O}_{3}$ were carried out using Thermo-Fisher chemiluminescent detectors [Model 42C $\left(\mathrm{NO}_{\mathrm{x}}\right)$ and $49 \mathrm{C}\left(\mathrm{O}_{3}\right)$, respectively].

\subsection{Measurement System for Nitrate Radical}

The DOAS system during PRD field campaign has been used in a past field campaign. The details of its opera- tion have been presented elsewhere ( $\mathrm{Li}$ et al. 2007); here, only a short description is given. Figure 2 shows the important parts of the DOAS system for measuring the nitrate radical. A Cassegrain telescope was used to transmit and receive light, which was reflected by an array of 13 retroreflectors. The light was transmitted to the spectrograph and then to the detector via a $7 \times 0.1 \mathrm{~mm}$ diameter fiber bundle, which was regulated by a mode mixer to reduce the interference fringe produced by the total reflections inside the fiber of the light leaving the fiber. The spectrograph was an Andor Shamrock SR-303i with a focal length of $303 \mathrm{~mm}$, a linear dispersion of $2.6 \mathrm{~nm} \mathrm{~mm}^{-1}$, and diffraction grating with 600 groves $\mathrm{mm}^{-1}$. In order to reduce dark current, the Andor iDUS CCD detector was cooled down to $-45^{\circ} \mathrm{C}$ by a Peltier cascade. A $610 \mathrm{~nm}$ long pass red filter, to reduce stray light effects below $610 \mathrm{~nm}$, was placed in the fiber optic coupler. Finally, the spectral signal was stored and analyzed in a computer. The integration time of the measurement spectra was adjusted automatically to the incoming light intensity, so the nitrate radical could be retrieved every 2 - 15 minutes while evaluating the spectral range between 647 and $677 \mathrm{~nm}$

\section{NITRATE RADICAL CHEMISTRY IN THE BOUNDARY}

The nitrate radical is formed by the reaction of $\mathrm{NO}_{2}$ with $\mathrm{O}_{3}$ in the boundary layer (Noxon 1980; Wayne et al. 1991; Geyer et al. 2001; Brown et al. 2003a; Platt et al. 2002; Vrekoussis et al. 2004):

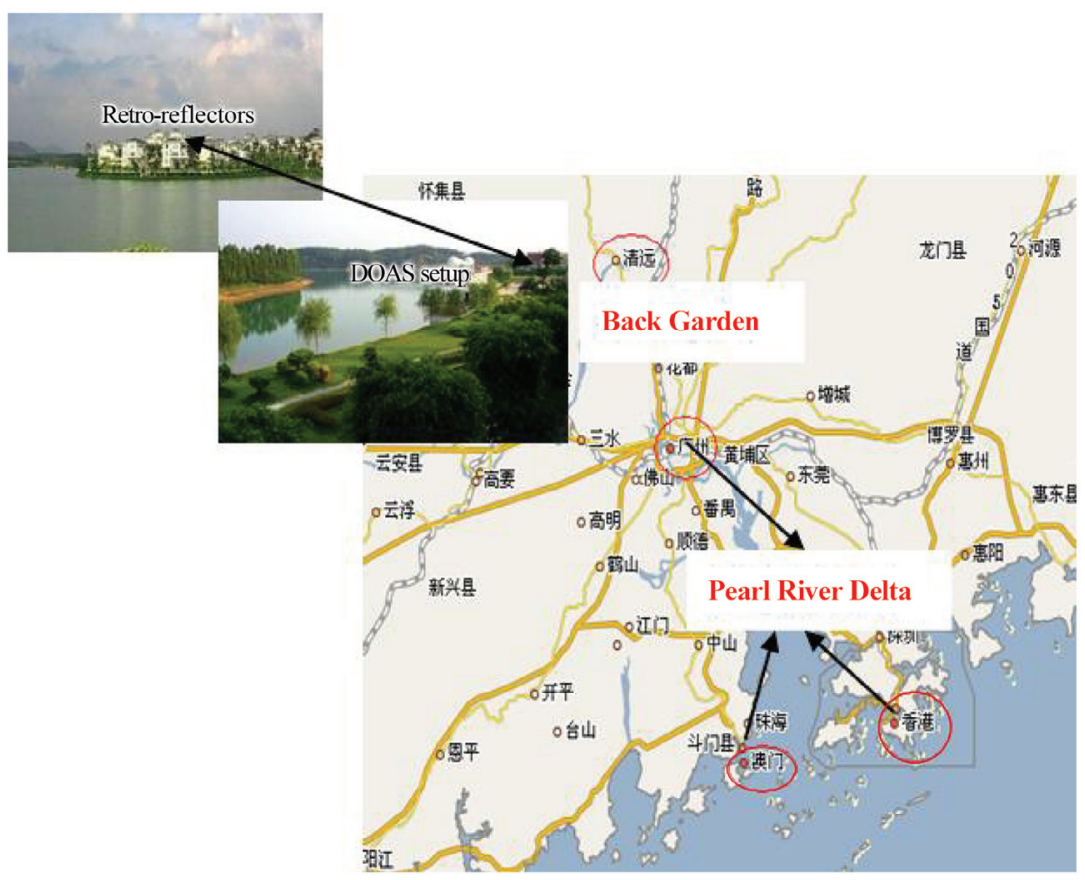

Fig. 1. Map monitoring the site during PRD summer field campaign. 


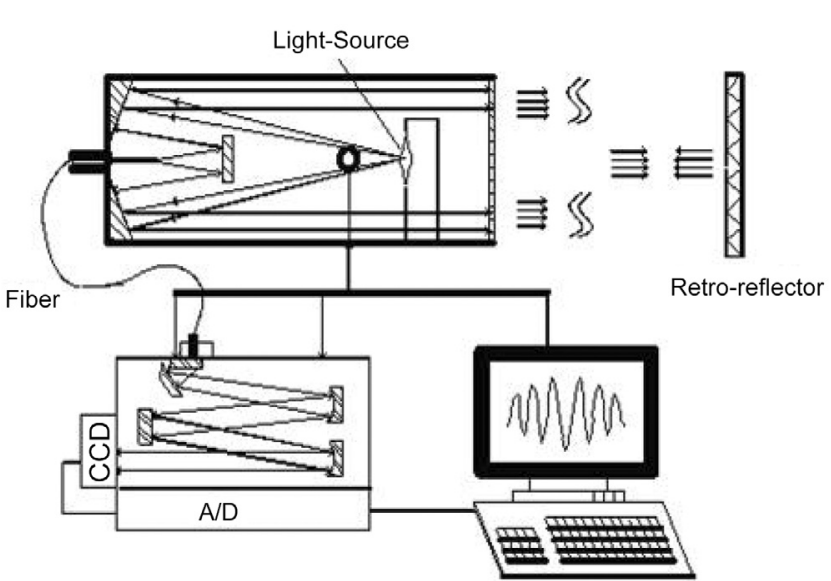

Fig. 2. Schematic view of a LP-DOAS experimental setup for $\mathrm{NO}_{3}$ measurement.

$\mathrm{NO}_{2}+\mathrm{O}_{3} \rightarrow \mathrm{NO}_{3}+\mathrm{O}_{2}$

with the reaction rate: $\mathrm{k}_{1}=1.4 \times 10^{-13} \exp (-2470 / \mathrm{T}) \mathrm{cm}^{3} \mathrm{~s}^{-1}$, $\mathrm{k}_{1}(298 \mathrm{~K})=3.55 \times 10^{-17} \mathrm{~cm}^{3} \mathrm{~s}^{-1}$ (http://www.iupac-kinetic. ch.cam.ac.uk).

The nitrate radical reacts further with $\mathrm{NO}_{2}$ to produce $\mathrm{N}_{2} \mathrm{O}_{5}$, some of which thermally decomposes to produce $\mathrm{NO}_{3}$ and $\mathrm{NO}_{2}$ again:

$\mathrm{NO}_{3}+\mathrm{NO}_{2}+\mathrm{M} \Leftrightarrow \mathrm{N}_{2} \mathrm{O}_{5}+\mathrm{M}$

The strongly temperature dependent equilibrium rate is $\mathrm{K}_{\mathrm{eg}}(\mathrm{T})=9.7 \times 10^{14}(\mathrm{~T} / 300)^{0.01} \exp (-11080 / \mathrm{T}) \mathrm{cm}^{3} \mathrm{~s}^{-1}$.

During the daytime, $\mathrm{NO}_{3}$ has a very short lifetime of about 5 s (Heintz et al. 1996; Geyer et al. 2001; McLaren et al. 2004) due to its rapid photolysis. The photolysis frequency for solar zenith angles below $70^{\circ}$ is about $0.2 \mathrm{~s}^{-1}$ (Geyer et al. 2001; Platt et al. 2002; Vrekoussis et al. 2004):

$\mathrm{NO}_{3}+\mathrm{h} v \rightarrow \mathrm{NO}_{2}+\mathrm{O}\left({ }^{3} \mathrm{P}\right)$

$\mathrm{NO}_{3}+\mathrm{h} v \rightarrow \mathrm{NO}+\mathrm{O}_{2}$

A rapid loss mechanism is the gas phase reaction with NO in the polluted boundary (Geyer et al. 2001; Platt et al. 2002):

$\mathrm{NO}_{3}+\mathrm{NO} \rightarrow \mathrm{NO}_{2}+\mathrm{NO}_{2}$

The reaction rate is $\mathrm{k}_{5}=1.8 \times 10^{-11} \exp (110 / \mathrm{T}) \mathrm{cm}^{3} \mathrm{~s}^{-1}$, $\mathrm{k}_{5}(298 \mathrm{~K})=2.6 \times 10^{-11} \mathrm{~cm}^{3} \mathrm{~s}^{-1}$. Reaction (5) is a daytime sink for $\mathrm{NO}_{3}$ that can be much more important than photolysis under polluted conditions. For instance, lifetime of $\mathrm{NO}_{3}$ is about $0.1-0.5 \mathrm{~s}^{-1}$ at $\mathrm{NO}$ levels of $2.5-0.5 \mathrm{ppb}$. However, if the $\mathrm{NO}$ is recently injected into the air mass sampled, then a decomposing $\mathrm{N}_{2} \mathrm{O}_{5}$ source could support some level of steady state $\mathrm{NO}_{3}$ before it is quenched by $\mathrm{NO}$ (Brown et al. 2003b).

In addition, $\mathrm{NO}$ is rapidly oxidized by the reaction with ozone:

$\mathrm{O}_{3}+\mathrm{NO} \rightarrow \mathrm{NO}_{2}+\mathrm{O}_{2}$

Rate constant is $\mathrm{k}_{6}(298 \mathrm{~K})=1.8 \times 10^{-14} \mathrm{~cm}^{3} \mathrm{~s}^{-1}$, resulting in typical lifetime of $\mathrm{NO}$ of the order 1 minute at $30 \mathrm{ppb}$ ozone.

In a marine atmosphere, the reaction of $\mathrm{NO}_{3}$ with dimethylsulfide (DMS) is of importance (Carslaw et al. 1997; Allan et al. 1999; Vrekoussis et al. 2004). However, the discussion will be restricted to the nitrate radical in the continental boundary layer, which reacts with VOCs, in particular alkenes (e.g., monoterpenes) (Mihelcic et al. 1993; Smith et al. 1995; Carslaw et al. 1997; Geyer et al. 2001). Nitrate radicals can noticeably contribute to the degradation of several hydrocarbons in the nighttime atmosphere. Some rate constants for the reactions with $\mathrm{NO}_{3}$ are even comparable to that with $\mathrm{OH}$ (e.g., Atkinson et al. 1990; Heintz et al. 1996; Geyer et al. 2001).

Since $\mathrm{NO}_{3}$ is in equilibrium with $\mathrm{N}_{2} \mathrm{O}_{5}$, the sink process for $\mathrm{N}_{2} \mathrm{O}_{5}$ will affect the $\mathrm{NO}_{3}$ concentration and its lifetime. The homogeneous reaction with water vapor is a possible sink of $\mathrm{N}_{2} \mathrm{O}_{5}$, producing gaseous $\mathrm{HNO}_{3}$, and rate constant is about $3 \sim 9 \times 10^{-22} \mathrm{~cm}^{3} \mathrm{~s}^{-1}$ (Carslaw et al. 1997; Allan et al. 1999; Vrekoussis et al. 2004):

$\mathrm{N}_{2} \mathrm{O}_{5}+\mathrm{H}_{2} \mathrm{O} \rightarrow 2 \mathrm{HNO}_{3}$

On the other hand a heterogeneous reaction on wet particulate surfaces form particulate nitrate:

$\mathrm{N}_{2} \mathrm{O}_{5}+\mathrm{H}_{2} \mathrm{O}_{(\mathrm{p})} \rightarrow 2 \mathrm{HNO}_{3(\mathrm{p})}$

The reaction of $\mathrm{N}_{2} \mathrm{O}_{5}$ on aerosol surfaces is another possible sink of $\mathrm{N}_{2} \mathrm{O}_{5} \cdot \mathrm{N}_{2} \mathrm{O}_{5}$ can also be removed by dry deposition to the ground (Geyer et al. 1999, 2001; Stutz et al. 2004).

\section{RESULTS AND DISCUSSION}

\subsection{Meteorological Data}

Figure 3 gives an overview of the meteorological data at Back Garden. A multitude of meteorological parameters including temperature, relative humidity, wind speed and wind direction were monitored at the measurement site. The temperature and relative humidity were a typical diurnal variation with mean values of $303 \mathrm{~K}$ and $79 \%$, respectively. 


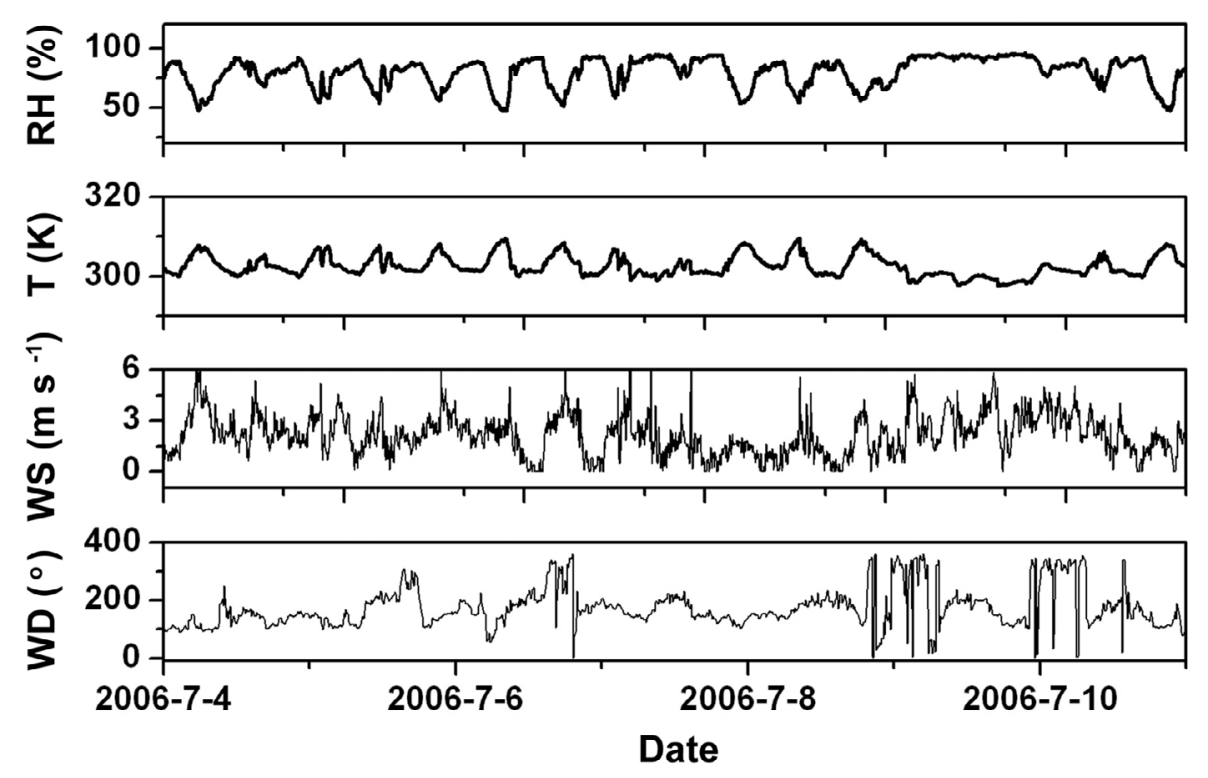

Fig. 3. Time series of the meteorological parameters.

Usually, wind speed was below $6 \mathrm{~m} \mathrm{~s}^{-1}$ at an average of $2.1 \mathrm{~m} \mathrm{~s}^{-1}$. The frequency distribution of the wind direction was shown in Fig. 4. The prevailing wind direction was characterized by southeast during this campaign. The measurement site (seen in Fig. 1) was located in the northwest of the Pearl River Delta, and measurement was sampling outflow from the PRD mega-cities.

\subsection{The Concentrations of $\mathrm{NO}_{3}, \mathrm{O}_{3}, \mathrm{NO}$, and $\mathrm{NO}_{2}$}

The nitrate radical was measured from July 4 to 11 , 2006 at Back Garden during an intensive field campaign in $\mathrm{PRD}$ region. Figure 5a shows the time series of $\mathrm{NO}_{3}$ concentrations. Its nighttime average was about $21.8 \pm 1.8 \mathrm{ppt}$ with the detection limits of about 3.6 ppt. $\mathrm{NO}_{3}$ at this level can play a significant role in oxidation of volatile organic compounds (VOCs). The level was slightly higher than those shown in several previous studies that also used the DOAS method (Heintz et al. 1996; Geyer et al. 2001; McLaren et al. 2004). Recently, Brown et al. (2003a, b, 2006b) using a cavity ring-down spectroscopy (CaRDS) instrument for in situ quantification have indicated $\mathrm{NO}_{3}$ and $\mathrm{N}_{2} \mathrm{O}_{5}$ are significantly higher.

The data in Fig. 5 display several interesting features whose description and analysis will be discussed in the next section. These include the influence of $\mathrm{NO}$ concentrations on the $\mathrm{NO}_{3}$ and $\mathrm{N}_{2} \mathrm{O}_{5}$ levels, the equilibrium between $\mathrm{NO}_{2}$, $\mathrm{NO}_{3}$ and $\mathrm{N}_{2} \mathrm{O}_{5}$.

Figures $5 \mathrm{~b}$ and $\mathrm{c}$ show the concentrations of $\mathrm{O}_{3}$ and $\mathrm{NO}$, respectively. The concentration of $\mathrm{O}_{3}$ showed a typical diurnal variation with maximum mixing ratios of $118 \mathrm{ppb}$ and an average of $38 \mathrm{ppb}$. As for NO, its average was at $8 \mathrm{ppb}$ during this campaign. The time series of the $\mathrm{NO}_{2}$ concentra- tion were showed in Fig. 5d, whose average was $18 \mathrm{ppb}$ in the nighttime.

Figure 6 shows the rose plots of $\mathrm{NO}_{3}, \mathrm{NO}, \mathrm{NO}_{2}$ and $\mathrm{O}_{3}$ concentrations with wind direction. For $\mathrm{NO}_{3}$ is a kind of highly reactive radical species with short atmospheric lifetime, $\mathrm{NO}_{3}$ remained at a low level and showed no obvious relationship with regard to a wind direction. The distributions of $\mathrm{NO}$ and $\mathrm{NO}_{2}$ were a consistent tendency when the southeast wind was popular during the field campaign. As a secondary pollutant, $\mathrm{O}_{3}$ was manly distributed when the wind direction was southeast. Its sources were transportation and the local photochemical formation. Figure 7 shows the average diurnal patterns of $\mathrm{NO}, \mathrm{NO}_{2}$ and the $\mathrm{NO}_{2}$-to$\mathrm{NO}_{\mathrm{x}}$ ratio, respectively. The diurnal trend of $\mathrm{NO}$ and $\mathrm{NO}_{2}$

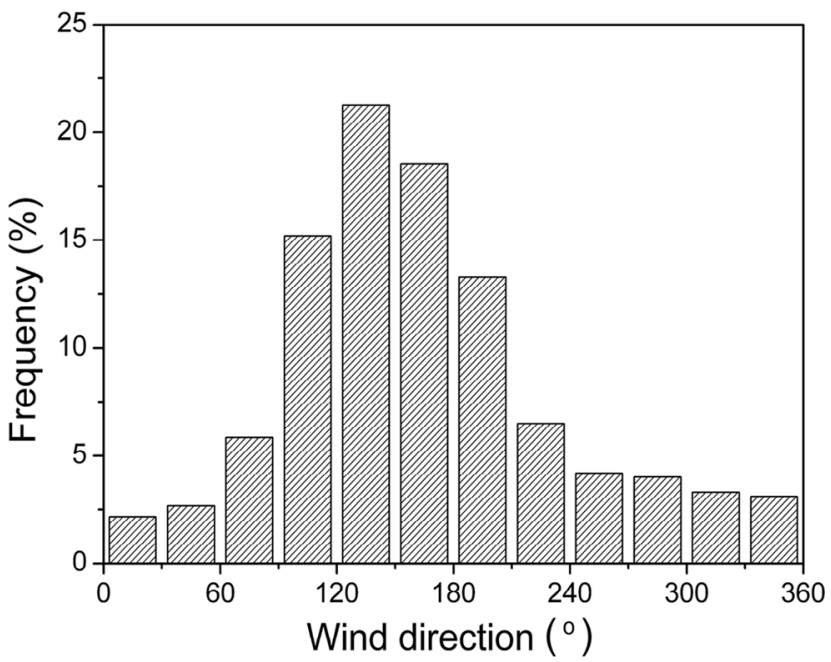

Fig. 4. A frequency distribution of wind direction. 


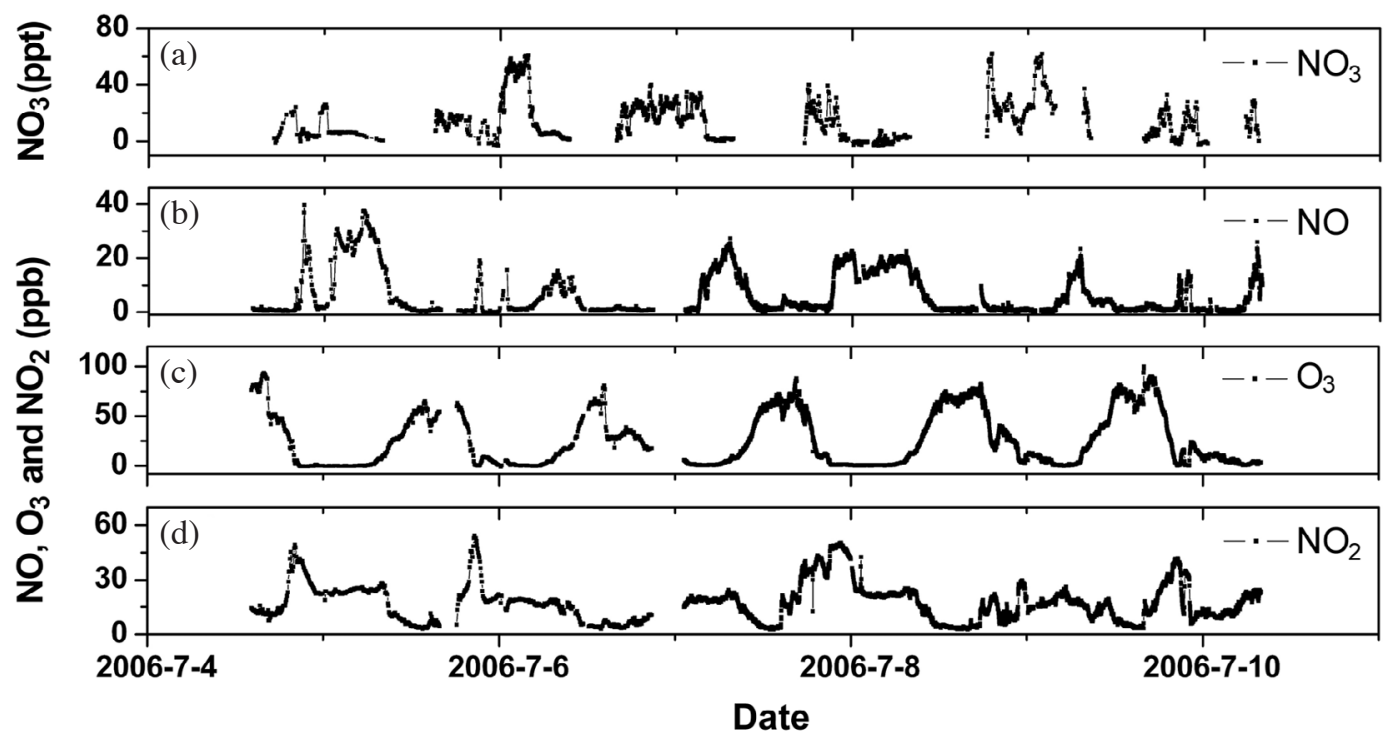

Fig. 5. Time series of the concentrations of (a) $\mathrm{NO}_{3}$ in ppt, (b) $\mathrm{NO}$ in ppb, (c) $\mathrm{O}_{3}$ in ppb and (d) $\mathrm{NO}_{2}$ in ppb during this campaign.
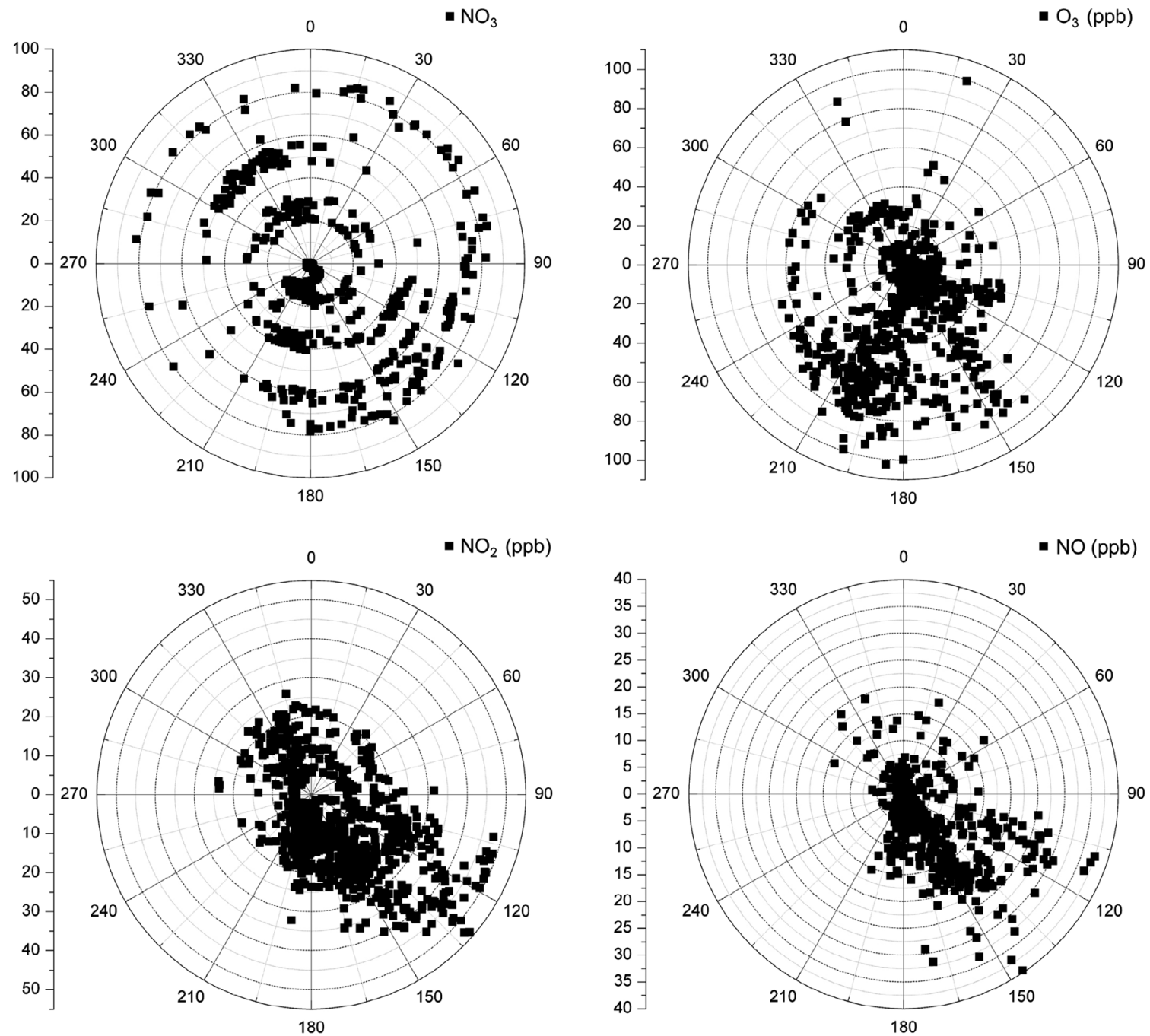

Fig. 6. Rose plots of $\mathrm{NO}_{3}, \mathrm{O}_{3}, \mathrm{NO}_{2}$ and $\mathrm{NO}$ concentrations with wind direction. 


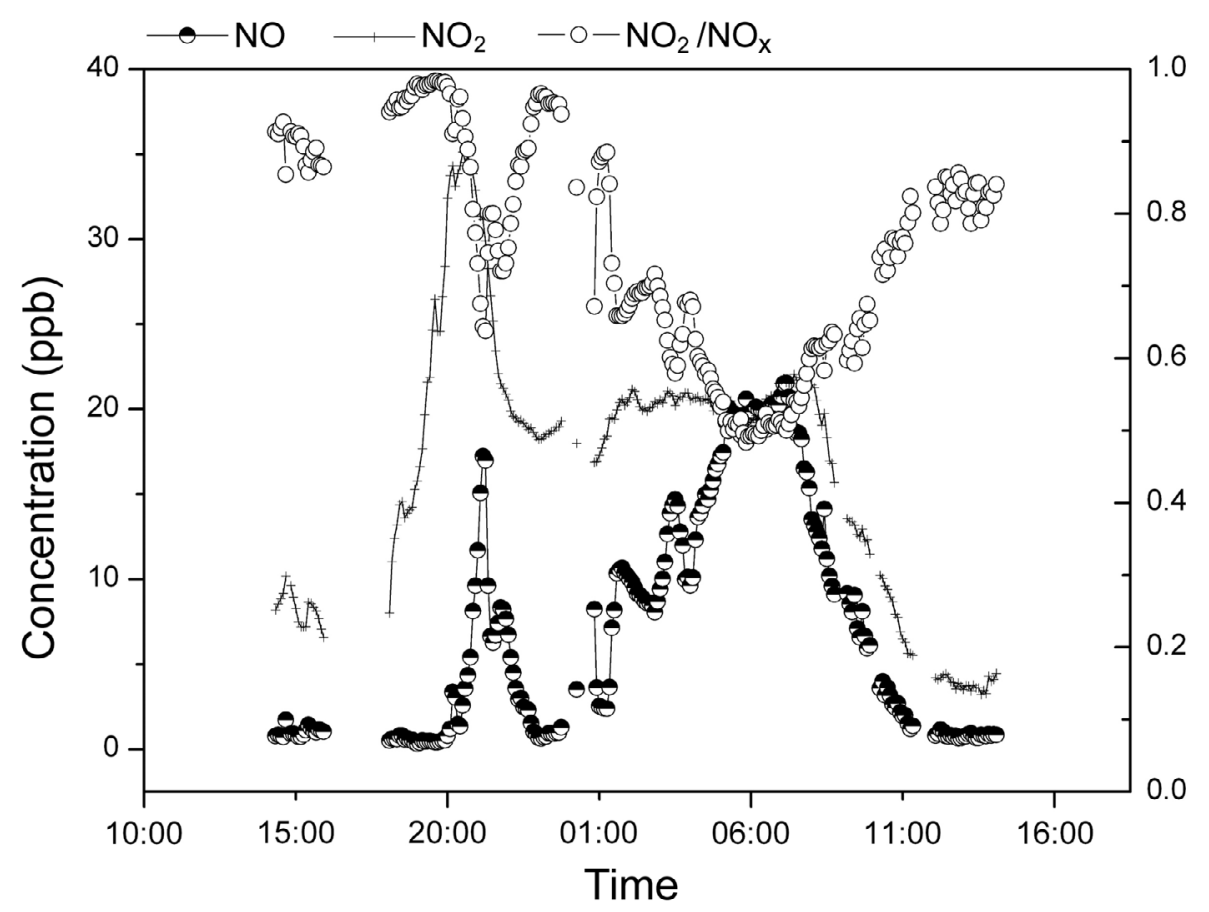

Fig. 7. Average diurnal patterns of $\mathrm{NO}, \mathrm{NO}_{2}$ and the $\mathrm{NO}_{2}$-to- $\mathrm{NO}_{\mathrm{x}}$ ratio.

was similar, and the $\mathrm{NO}_{2}$-to- $\mathrm{NO}_{\mathrm{x}}$ ratio was bigger than 0.5 (Jenkin 2004). Therefore, these results further indicated that $\mathrm{NO}$ and $\mathrm{NO}_{2}$ came from the PRD.

\subsection{Production Rate and Lifetime of Nitrate Radical}

Since the only significant source of $\mathrm{NO}_{3}$ is reaction (1), the production rate of nitrate radical, $\mathrm{P}\left(\mathrm{NO}_{3}\right)$, could be calculated:

$\mathrm{P}\left(\mathrm{NO}_{3}\right)=\left[\mathrm{NO}_{2}\right]\left[\mathrm{O}_{3}\right] \mathrm{k}_{1}$

Figure 8 was the calculated production rate of $\mathrm{NO}_{3}$ when the data were available. The production rate generally varied from $1 \times 10^{5} \mathrm{~cm}^{-3} \mathrm{~s}^{-1}$ to $3.7 \times 10^{7} \mathrm{~cm}^{-3} \mathrm{~s}^{-1}$ with an average value of $5.1 \times 10^{6} \mathrm{~cm}^{-3} \mathrm{~s}^{-1}$.

A steady state occurred considerably more rapidly at a warmer temperature, for example $300 \mathrm{~K}$ (Brown et al. 2003a, b). Therefore, we assumed that it was in a steady state; lifetimes were given by (Heintz et al. 1996; Geyer et al. 2001; Brown et al. 2006a):

$\tau\left(\mathrm{NO}_{3}\right)=\frac{\left[\mathrm{NO}_{3}\right]}{\left[\mathrm{NO}_{2}\right]\left[\mathrm{O}_{3}\right] \mathrm{k}_{2}}=\frac{\left[\mathrm{NO}_{3}\right]}{\mathrm{P}\left(\mathrm{NO}_{3}\right)}$

The calculated lifetimes of $\mathrm{NO}_{3}$ were in the range several to 650 seconds with an average value of 89 seconds (seen Fig. 9).

\subsection{Time Series of $\mathrm{N}_{2} \mathrm{O}_{5}$}

Although $\mathrm{N}_{2} \mathrm{O}_{5}$ could not directly be measured with DOAS, its equilibrium concentration can be calculated from the measured levels of $\mathrm{NO}_{2}, \mathrm{NO}_{3}$, and temperature:

$$
\left[\mathrm{N}_{2} \mathrm{O}_{5}\right]=\mathrm{K}_{\mathrm{eq}}(\mathrm{T})\left[\mathrm{NO}_{2}\right]\left[\mathrm{NO}_{3}\right]
$$

Field studies of this equilibrium in which all three components were measured showed that it was in agreement with the calculated equilibrium to within $30 \%$ (Brown et al. 2003a); therefore, this was a reasonable estimate for the uncertainty of the calculated $\mathrm{N}_{2} \mathrm{O}_{5}$. The calculated peak mixing ratio of $\mathrm{N}_{2} \mathrm{O}_{5}$ was 2054 ppt with the average of 298 \pm 89 ppt (seen in Fig. 10).

\subsection{Possible Loss Process}

Because of the lack of ancillary measurement (e.g., VOCs), it is not possible to quantitatively identify the nature of the sinks for $\mathrm{NO}_{3}$. Several possibilities can be obtained by analyzing the correlation between $\mathrm{NO}_{3}$ and its production rate $\left[\mathrm{P}\left(\mathrm{NO}_{3}\right)\right], \mathrm{NO}_{3}$ lifetime $\left[\tau\left(\mathrm{NO}_{3}\right)\right]$ and $\mathrm{NO}_{2}, \mathrm{NO}_{3}$ and NO, respectively (Allan et al. 1999; Geyer et al. 2001).

As a first step, the correlation between $\mathrm{NO}_{3}$ and its productive rate was studied to estimate the impact of direct sinks at Bark Garden in Guangzhou. Figure 11 showed $\mathrm{NO}_{3}$ concentration as a function of its production rate separated in the intervals of $\mathrm{P}\left(\mathrm{NO}_{3}\right)$ of length $5 \times 10^{6} \mathrm{~cm}^{-3} \mathrm{~s}^{-1}$. The 
data was in good agreement with a regression coefficient $\mathrm{R}$ $=0.8$ between $\mathrm{P}\left(\mathrm{NO}_{3}\right)$ and $\left[\mathrm{NO}_{3}\right]$, which indicated that the direct loss of the nitrate radical are much important under polluted air masses at the measurement site.

The reaction of $\mathrm{NO}_{3}$ with $\mathrm{NO}$ can be a very rapid direct sink for $\mathrm{NO}_{3}$ under a polluted air mass. Nocturnal concentrations of NO, however, are generally quite small because the reaction with ozone converts this compound into $\mathrm{NO}_{2}$ within a few minutes. In the absence of photolytic conversion of
$\mathrm{NO}_{2}$ back to $\mathrm{NO}$, the concentration of $\mathrm{NO}$ falls essentially to zero. But local sources can provide nonzero levels of $\mathrm{NO}$, which in turn have a clear impact on observed $\mathrm{NO}_{3}$ and $\mathrm{N}_{2} \mathrm{O}_{5}$ concentrations. A clear tendency of higher $\mathrm{NO}_{3}$ levels at lower NO is found in Fig. 12. Sometimes both NO and $\mathrm{NO}_{3}$ were high in the morning in several later peaks. Based on a technical characteristic between $\mathrm{NO}$ and $\mathrm{NO}_{3}$ measurement, this may be caused by the difference in the measuring condition (different air mass etc.). $\mathrm{NO}_{3}$ was measured along

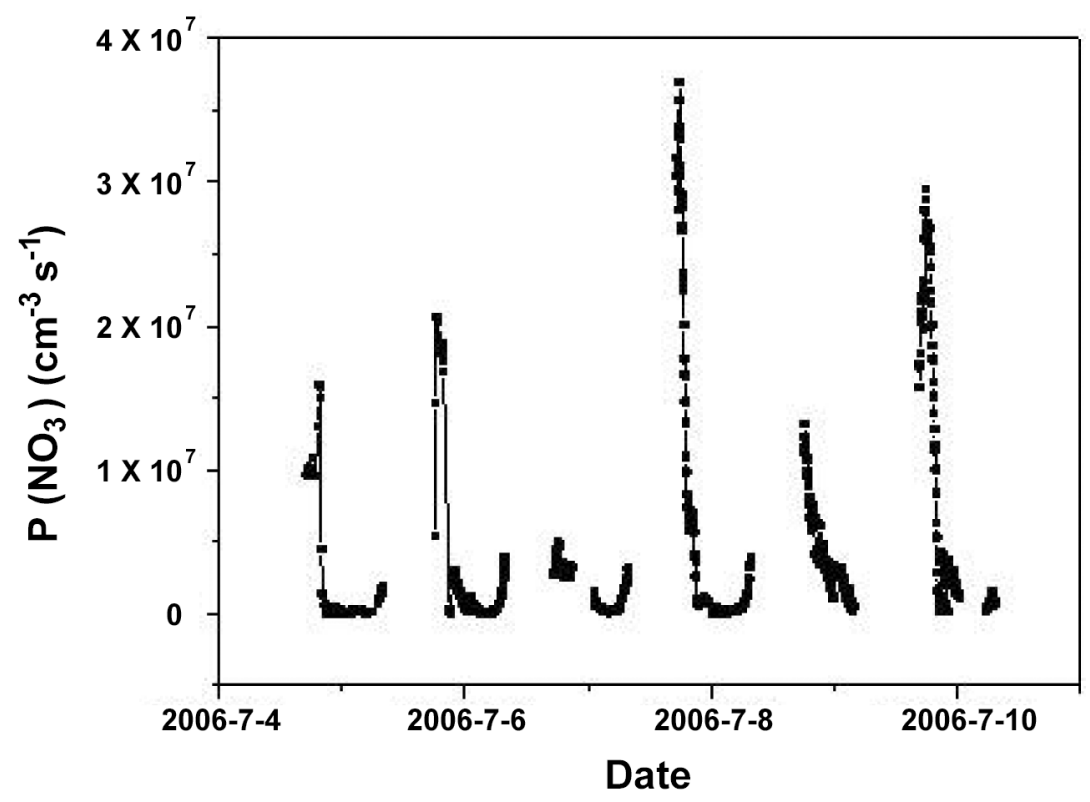

Fig. 8. Time series of the productive rate of $\mathrm{NO}_{3}$.

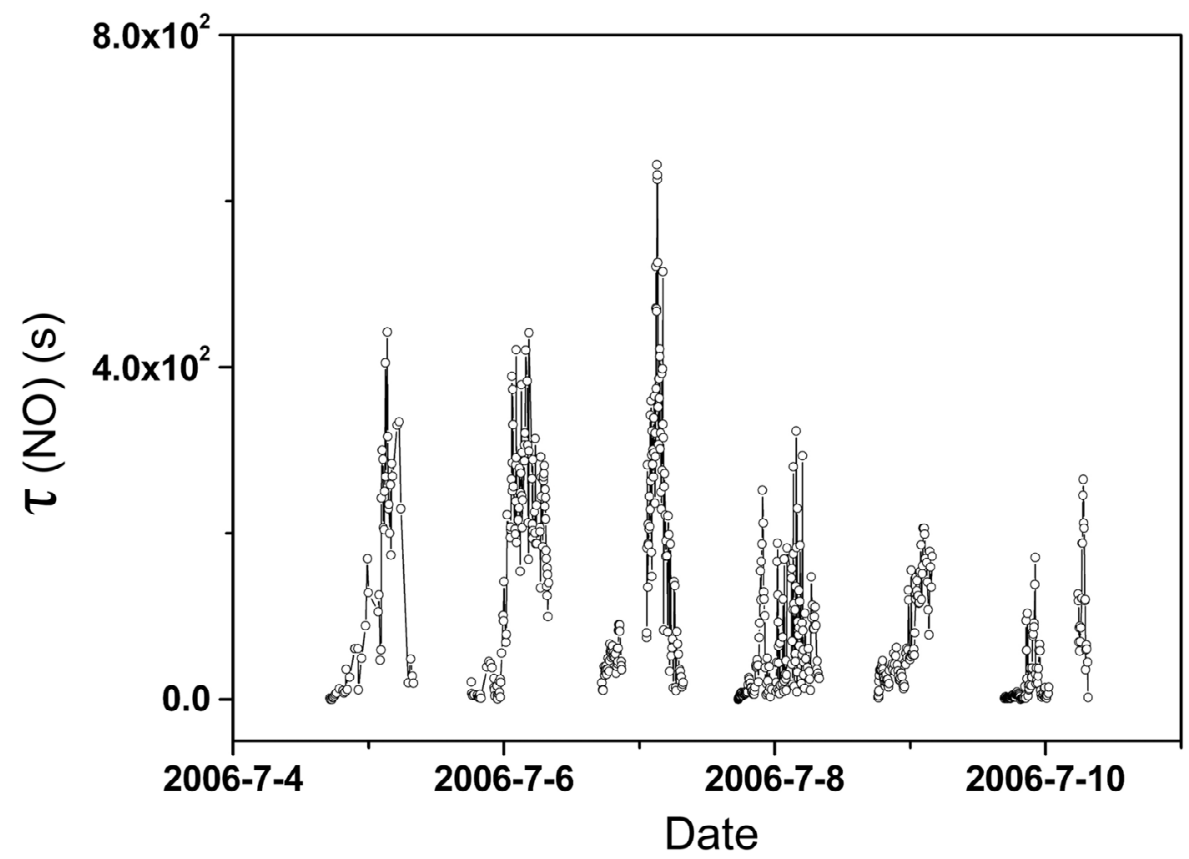

Fig. 9. Time series of the lifetimes of $\mathrm{NO}_{3}$. 


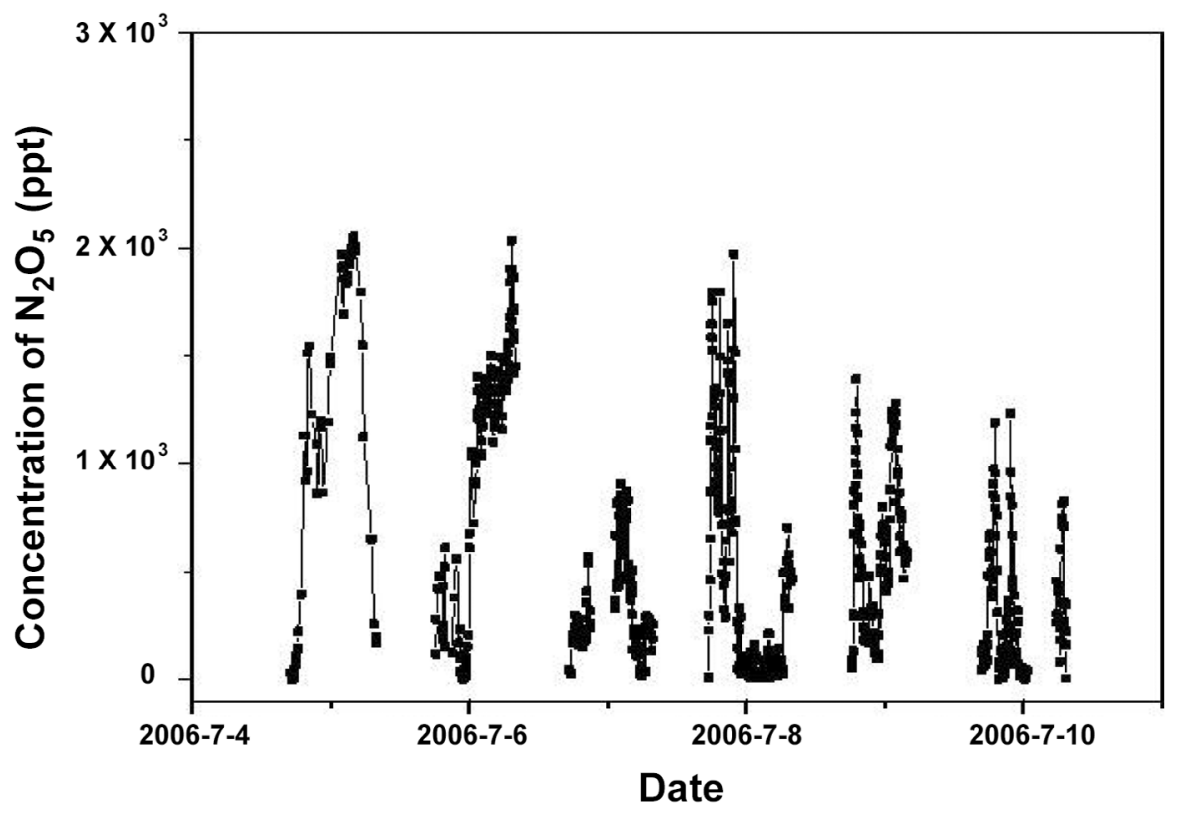

Fig. 10. The time series of calculated $\mathrm{N}_{2} \mathrm{O}_{5}$ concentrations.

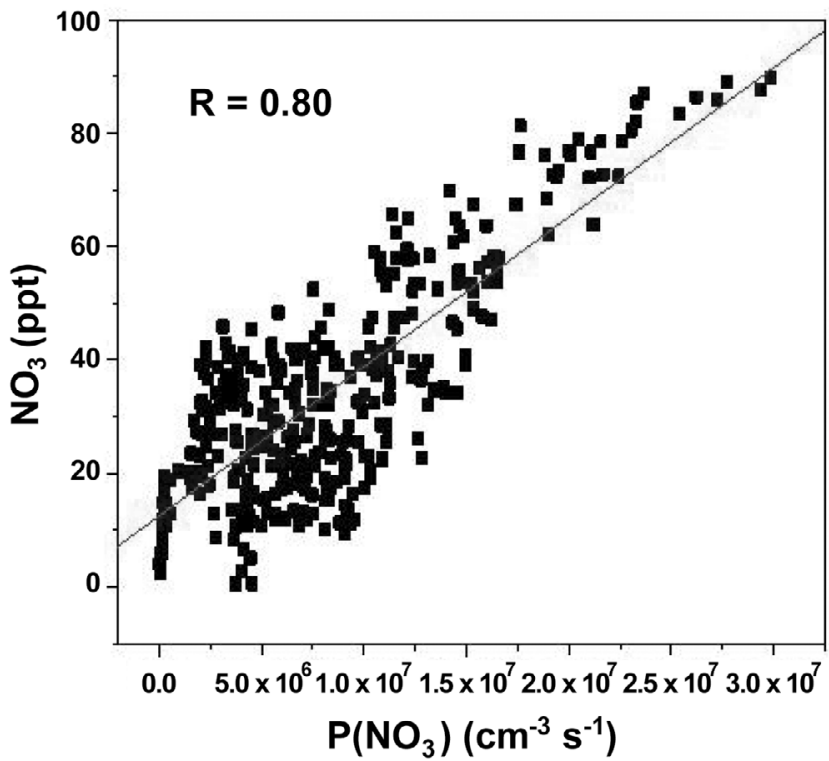

Fig. 11. The $\mathrm{NO}_{3}$ concentration as a function of its production rate.

with optical path of $3.1 \mathrm{~km}$ on the average. Analysis of the $\mathrm{NO}$ was carried out using point-instrument.

A negative correlation between the $\mathrm{NO}_{3}$ lifetime and $\mathrm{NO}_{2}$ concentration, which is usually presented as evidence of the predominance of $\mathrm{N}_{2} \mathrm{O}_{5}$ loss over $\mathrm{NO}_{3}$ loss mechanisms (Geyer 2000), was only found to exist in relative humidity above 58\% (Wood et al. 2005). The mean relative humidity was about $79 \%$ during this campaign, which is near the deliquescence relative humidity of many common aerosol systems suggesting that most aerosol particles were in a liquid phase. Uptake of $\mathrm{N}_{2} \mathrm{O}_{5}$ is, in general, much faster onto aqueous aerosols than onto solid aerosols. Therefore, in order to prove the existence and importance of indirect loss pathways the correlation between the lifetime of $\mathrm{NO}_{3}$ and concentration of $\mathrm{NO}_{2}$ was studied (Fig. 13). The analysis was restricted to data with $\mathrm{NO}_{3}$ and $\mathrm{NO}_{2}$ above the detection limits. The lifetime of $\mathrm{NO}_{3}$ rapidly dropped at $\mathrm{NO}_{2}$ higher than $40 \mathrm{ppb}$, for $\tau\left(\mathrm{NO}_{3}\right)$ is inverse proportion to $\mathrm{NO}_{2}$ from Eq. (10). A linear fit was performed for the statistical values of $\mathrm{NO}_{2}$ and $\tau\left(\mathrm{NO}_{3}\right)$ yielding a correlation coefficient $\mathrm{R}=-0.52$ indicating indirect sinks play a role in determining $\mathrm{NO}_{3}$ concentrations during this campaign.

Therefore, there was evidence from statistical analysis of correlations showing adirect loss process was much more significant at the Back Garden site during this campaign. Under polluted conditions, possible sinks for $\mathrm{NO}_{3}$ were similar to those in Los Angeles and in Colorado (Platt et al. 1980; Brown et al. 2003b).

\section{CONCLUSIONS}

The nighttime nitrate radical was measured by using long path DOAS in the continental boundary layer in the Pearl River Delta (PRD). The mean value of the nitrate radical was $21.8 \pm 1.8 \mathrm{ppt}$ during this campaign. An assessment of $\mathrm{NO}_{3}$ lifetimes using concentration of $\mathrm{O}_{3}$ and $\mathrm{NO}_{2}$ averaged 89 seconds. The calculated peak mixing ratio of $\mathrm{N}_{2} \mathrm{O}_{5}$ was 3424 ppt with the average of $620 \pm 93$ ppt. The possible loss processes of $\mathrm{NO}_{3}$ were also discussed basing on statistical analysis of the correlation of nitrate radical and supporting parameters in this paper. The direct losses were important sinks for $\mathrm{NO}_{3}$ at Back Garden in summer Pearl River Delta. 


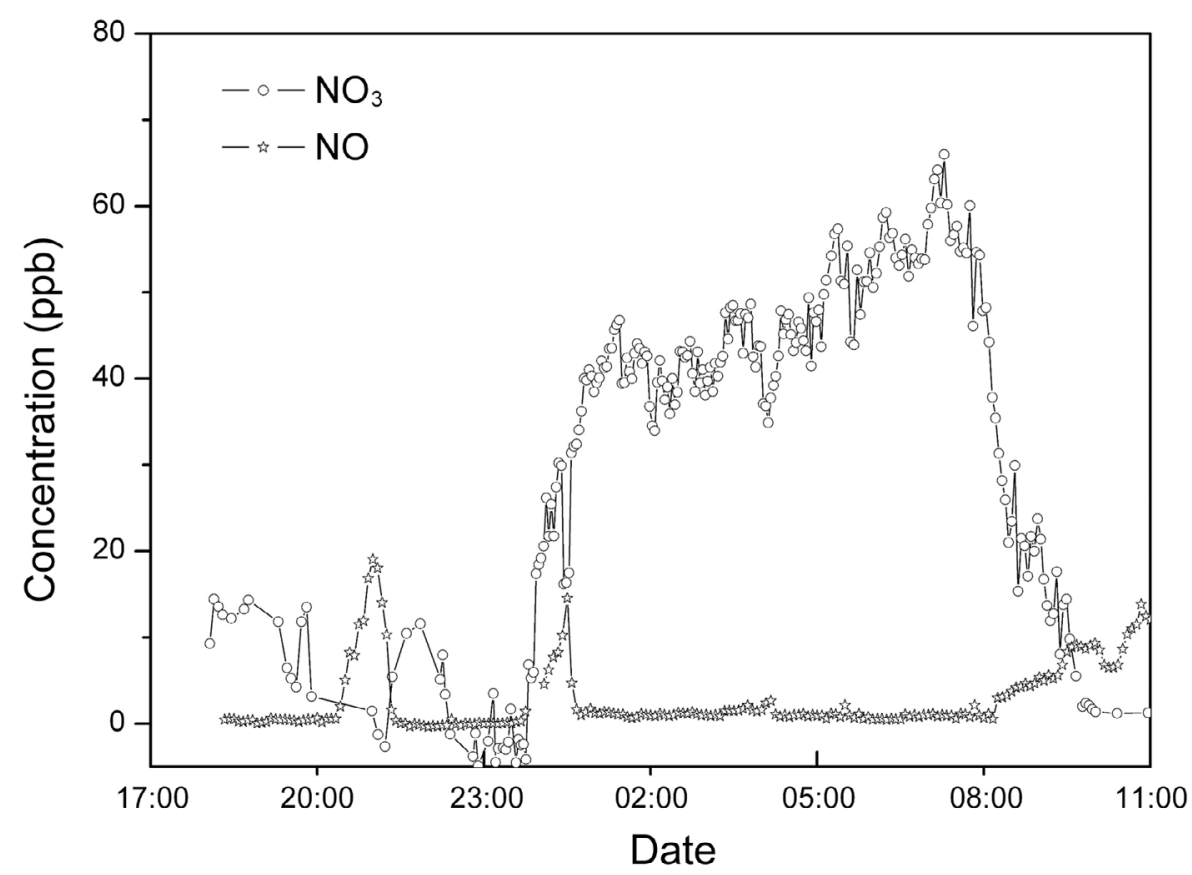

Fig. 12. Average diurnal patterns of $\mathrm{NO}, \mathrm{NO}_{3}$ concentrations and $\mathrm{NO}_{2}$ concentration.

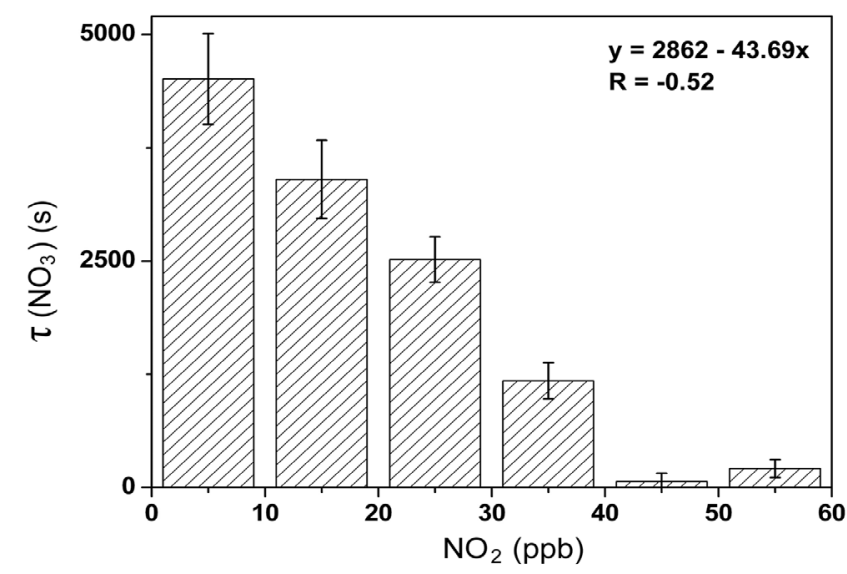

Fig. 13. The correlation of calculated $\mathrm{NO}_{3}$ life times and $\mathrm{NO}_{2}$ concentrations; the error bars for $\mathrm{NO}_{3}$ life times represent the standard deviation.

Acknowledgement We offer thanks to the DOAS groups, Peking University and Sun yet-sen University for their help. This project was supported by the Natural Science Foundation of Anhui Province Colleges and University (KJ2012ZD002), the Key Project of Chinese Ministry of Education (209057), Anhui Provincial Natural Science Foundation (090412028), and China and the National Natural Science Foundation of China (60808034).

\section{REFERENCES}

Allan, B. J., N. Carslaw, H. Coe, R. A. Burgess, and J. M. C.
Plane, 1999: Observations of the nitrate radical in the marine boundary layer. J. Atmos. Chem., 33, 129-154, doi: 10.1023/A:1005917203307. [Link]

Atkinson, R., S. M. Aschmann, and J. Arey, 1990: Rate constants for the gas-phase reactions of $\mathrm{OH}$ and $\mathrm{NO}_{3}$ radicals and $\mathrm{O}_{3}$ with sabinene and camphene at $296 \pm 2 \mathrm{~K}$. Atmos. Environ., 24, 2647-2654, doi: 10.1016/0960-1 686(90)90144-C. [Link]

Bey, I., B. Aumont, and G. Toupance, 2001: A modeling study of the nighttime radical chemistry in the lower continental troposphere. 2. Origin and evolution of $\mathrm{HO}_{\mathrm{x}}$. J. Geophys. Res., 106, 9991-10001, doi: 10.1029/2000 JD900348. [Link]

Brown, S. S., H. Stark, and A. R. Ravishankara, 2003a: Applicability of the steady state approximation to the interpretation of atmospheric observations of $\mathrm{NO}_{3}$ and $\mathrm{N}_{2} \mathrm{O}_{5}$. J. Geophys. Res., 108, 4539, doi: 10.1029/2003 JD003407. [Link]

Brown, S. S., H. Stark, T. B. Ryerson, E. J. Williams, D. K. Nicks Jr., M. Trainer, F. C. Fehsenfeld, and A. R. Ravishankara, 2003b: Nitrogen oxides in the nocturnal boundary layer: Simultaneous in situ measurements of $\mathrm{NO}_{3}, \mathrm{~N}_{2} \mathrm{O}_{5}, \mathrm{NO}_{2}, \mathrm{NO}$, and $\mathrm{O}_{3}$. J. Geophys. Res., 108, 4299, doi: 10.1029/2002JD002917. [Link]

Brown, S. S., J. A. Neuman, T. B. Ryerson, M. Trainer, W. P. Dubé, J. S. Holloway, C. Warneke, J. A. de Gouw, S. G. Donnelly, E. Atlas, B. Matthew, A. M. Middlebrook, R. Peltier, R. J. Weber, A. Stohl, J. F. Meagher, F. C. Fehsenfeld, and A. R. Ravishankara, 2006a: Nocturnal odd-oxygen budget and its implications for ozone 
loss in the lower troposphere. Geophys. Res. Lett., 33, L08801, doi: 10.1029/2006GL025900. [Link]

Brown, S. S., T. B. Ryerson, A. G. Wollny, C. A. Brock, R. Peltier, A. P. Sullivan, R. J. Weber, W. P. Dubé, M. Trainer, J. F. Meagher, F. C. Fehsenfeld, and A. R. Ravishankara, 2006b: Variability in nocturnal nitrogen oxide processing and its role in regional air quality. Science, 311, 67-70, doi: 10.1126/science.1120120. [Link]

Carslaw, N., L. J. Carpenter, J. M. C. Plane, B. J. Allan, R. A. Burgess, K. C. Clemitshaw, H. Coe, and S. A. Penkett, 1997: Simultaneous observations of nitrate and peroxy radicals in the marine boundary layer. J. Geophys. Res., 102, 18917-18933, doi: 10.1029/97JD00399. [Link]

Geyer, A., 2000: The role of the nitrate radical in the boundary layer-observation and modeling studies. Dissertation, Heidelberg University.

Geyer,A., B. Alicke, D. Mihelcic, J. Stutz, and U.Platt, 1999: Comparison of tropospheric $\mathrm{NO}_{3}$ radical measurements by differential optical absorption spectroscopy and matrix isolation electron spin resonance. J. Geophys. Res., 104, 26097-26105, doi: 10.1029/1999JD900421. [Link]

Geyer, A., B. Alicke, S. Konrad, T. Schmitz, J. Stutz, and U. Platt, 2001: Chemistry and oxidation capacity of the nitrate radical in the continental boundary layer near Berlin. J. Geophys. Res., 106, D8, 8013-8025, doi: 10. 1029/2000JD900681. [Link]

Heintz, F., U. Platt, H. Flentje, and R. Dubois, 1996: Longterm observation of nitrate radicals at the Tor Station, Kap Arkona (Rügen). J. Geophys. Res., 101, 2289122910, doi: 10.1029/96JD01549. [Link]

Jenkin, M. E., 2004: Analysis of sources and partitioning of oxidant in the UK - Part 2: Contributions of nitrogen dioxide emissions and background ozone at a kerbside location in London. Atmos. Environ., 38, 5131-5138, doi: 10.1016/j.atmosenv.2004.05.055. [Link]

Li, S., W. Liu, P. Xie, A. Li, M. Qin, and K. Dou, 2007: Measurements of nighttime nitrate radical concentrations in the atmosphere by long-path differential optical absorption spectroscopy. Adv. Atmos. Sci., 24, 875880, doi: 10.1007/s00376-007-0875-2. [Link]

McLaren, R., R. A. Salmon, J. Liggio, K. L. Hayden, K. G. Anlauf, W. R. Leaitch , 2004: Nighttime chemistry at a rural site in the Lower Fraser Valley. Atmos. Environ., 38, 5837-5848, doi: 10.1016/j.atmosenv.2004.03.074. [Link]
Mihelcic,D.,D. Klemp,P. Müsgen,H. W.Pätz, and A. VolzThomas, 1993: Simultaneous measurements of peroxy and nitrate radicals at Schauinsland. J. Atmos. Chem., 16, 313-335, doi: 10.1007/BF01032628. [Link]

Noxon, J. F., R. B. Norton, and E. Marovich, 1980: $\mathrm{NO}_{3}$ in the troposphere. Geophys. Res. Lett., 7, 125-128, doi: 10.1029/GL007i002p00125. [Link]

Platt, U., D. Perner, A. M. Winer, G. W. Harris, and J. M. Pitts Jr., 1980: Detection of $\mathrm{NO}_{3}$ in the polluted troposphere by differential optical absorption. Geophys. Res. Lett., 7, 89-92, doi: 10.1029/GL007i001p00089. [Link]

Platt, U., G. Lebras, G. Poulet, J. P. Burrows, and G. Moortgat, 1990: Peroxy radicals from night-time reaction of $\mathrm{NO}_{3}$ with organic compounds. Nature, 348, 147-149, doi: 10.1038/348147a0. [Link]

Platt, U., B. Alicke, R. Dubois, A. Geyer, A. Hofzumahaus, F. Holland, M. Martinez, D. Mihelcic, T. Klüpfel, B. Lohrmann, W. Pätz, D. Perner, F. Rohrer, J. Schäfer, and J. Stutz, 2002: Free radicals and fast photochemistry during BERLIOZ. J. Atmos. Chem., 42, 359-394, doi: 10.1023/A:1015707531660. [Link]

Smith, N., J. M. C. Plane, C. F. Nien, and P. A. Solomon, 1995: Nighttime radical chemistry in the San Joaquin valley. Atmos. Environ., 29, 2887-2897, doi: 10.1016/1352-2310(95)00032-T. [Link]

Stutz, J., B. Alicke, R. Ackermann, A. Geyer, A. White, and E. Williams, 2004: Vertical profiles of $\mathrm{NO}_{3}, \mathrm{~N}_{2} \mathrm{O}_{5}$, $\mathrm{O}_{3}$, and $\mathrm{NO}_{\mathbf{x}}$ in the nocturnal boundary layer: Observations during the Texas Air Quality Study 2000. J. Geophy. Res., 109, D12306, doi: 10.1029/2003JD004209. [Link]

Vrekoussis, M., M. Kanakidou, N. Mihalopoulos, P. J. Crutzen, J. Lelieveld, D. Perner, H. Berresheim, and E. Baboukas, 2004: Role of the $\mathrm{NO}_{3}$ radicals in oxidation processes in the eastern Mediterranean troposphere during the MINOS campaign. Atmos. Chem. Phys., 4, 169-182, doi: 10.5194/acp-4-169-2004. [Link]

Wayne, R. P., I. Barnes, P. Biggs, J. P. Burrows, C. E. Canosa-Mas, J. Hjorth, G. L. Bras, G. K. Moortgat, D. Perner, G. Poulet, G. Restelli, and H. Sidebottom, 1991: The nitrate radical: Physics, chemistry, and the atmosphere. Atmos. Environ., 25, 1-203, doi: 10.1016/096 0-1686(91)90192-A. [Link]

Wood, E. C., T. H. Bertram, P. J. Wooldridge, and R. C. Cohen, 2005: Measurements of $\mathrm{N}_{2} \mathrm{O}_{5}, \mathrm{NO}_{2}, \mathrm{O}_{3}$ east of the San Francisco Bay. Atmos. Chem. Phys., 5, 483-491, doi: 10.5194/acp-5-483-2005. [Link] 